\title{
Stateless Person dalam Tinjauan Hukum Nasional dan Hukum Internasional di Indonesia
}

\author{
Khald Fadjri Siddiq*; Budi Ardianto \\ Fakultas Hukum Universitas Jambi \\ *Corresponding author: fadjrisuper@gmail.com
}

$\begin{array}{ll}\text { Submission } & : \text { 01 November } 2020 \\ \text { Revison } & : \text { 11 November } 2020 \\ \text { Publication } & : \text { 23 November } 2020\end{array}$

\begin{abstract}
This study aims to determine how Stateless persons are regulated based on international legal instruments and national legal instruments in Indonesia. Indonesia, which is affected by globalization due to the incessant promotion of tourism, has regulations on the traffic of foreigners through Law Number 6 of 2011 concerning Immigracy and on the other hand Indonesia does not recognize the existence of Stateless Persons which is different from the regulations as stated in the Convention Relating To The Status of Stateless Persons 1954. This study aims to find out that the current regulation regarding Stateless persons in Indonesia has not been specifically regulated. Although Indonesia has ratified the International Covenant on Civil and Political Rights. This shows that Indonesia has not strictly regulated and in its handling of Stateless people tends to be slow which results in detention exceeding the specified threshold. As for the formulation of the problem raised, namely how to regulate Stateless People in International Law and in Indonesian immigration law and the legal consequences obtained. The research method used is a normative type by means of literature study. The results of this study indicate that the arrangement for Stateless Persons in the international sphere is different from that in Indonesia because there are no strict regulations regarding this matter.
\end{abstract}

Keywords: Immigration; Refugees; Stateless Person 


\begin{abstract}
Abstrak
Penelitian ini bertujuan untuk mengetahui bagaimana pengaturan Orang Tanpa Kewarganegaraan atau Stateless Person berdasarkan instrumen hukum internasional maupun instrumen hukum nasional di Indonesia. Indonesia yang terdampak dalam globalisasi karena gencarnya promosi pariwisata memiliki pengaturan terhadap lalu lintas orang asing melalui Undang-undang Nomor 6 Tahun 2011 tentang Keimigrasiaan dan disisi lain Indonesia tidak mengakui keberadaan Orang Tanpa Kewarganegaraan berbeda dengan pengaturan sebagaiman tercantum dalam Convention Relating To The Status of Stateless Persons 1954. Penelitian ini bertujuan untuk mengetahui bahwa pengaturan mengenai Orang Tanpa Kewarganegaraan di Indonesia untuk saat ini belum diatur secara khusus. Walaupun Indonesia telah meratifikasi International Covenant on Civil and Political Rights. Hal ini menunjukkan bahwa Indonesia belum mengatur dengan tegas dan dalam penanganannya terhadap Orang Tanpa Kewarganegaraan cenderung lambat yang mengakibatkan pendetensian melebihi ambang dari batas yang ditentukan. Adapun rumusan masalah yang diangkat yakni bagaimana pengaturan Orang Tanpa Kewarganegaraan dalam Hukum Internasional dan dalam hukum keimigrasian Indonesia beserta konsukuensi hukum yang di dapat. Metode penelitian yang digunakan adalaha tipe normative dengan cara studi pustaka. Hasil penelitian ini menunjukkan bahwa pengaturan Orang Tanpa Kewarganegaraan di lingkup Internasional berbeda dengan pengaturan di Indonesia karena tidak adanya peraturan yang tegas mengenai hal ini.
\end{abstract}

\title{
Kata Kunci: Imigrasi; Orang Tanpa Kewarganegaraan; Pengungsi
}

\section{A. Pendahuluan}

Setiap negara memiliki kewajiban untuk menjamin dan menghormati hak asasi manusia, melindungi dan menegakkannya di negara masing-masing. Kewajiban ini tidak saja bersifat positif yaitu untuk ditegakkan atau diimpelementasikan. Dalam hal pengimpelementasian ini, terutama terhadap hak-hak asasi yang bersifat universal dan 
memiliki keberlakuan universal sebagaimana yang dirumuskan dalam deklarasi hak-hak asasi manusia. Oleh karena itu sebagaimana ditegaskan dalam Mukadimah Deklarasi Universal Hak Asasi Manusia/DUHAM, HAM perlu dilindungi dengan merumuskannya dalam instrument hukum agar orang tidak akan terpaksa memilih pemberontakan sebagai usaha terakhir guna menentang kezaliman dan penindasan sebagaimana ditunjukan dalam sejarah HAM itu. ${ }^{1}$

Pasal 15 Universal Declaration of Human Right menegaskan bahwa setiap orang mempunyai hak untuk memiliki kewarganegaraan, yakni ikatan hukum antara seseorang dengan suatu Negara. Identitas diri yang didapatkan dari kewarganegaraan dapat sekaligus termasuk kewenangan warga negara dalam menggunakan hak-hak yang melekat dalam dirinya.

Orang yang memiliki kewarganegaraan memiliki hak untuk ikut memilih tempat ia tinggal, mengajukan permohonan untuk mendapatkan dokumen perjalanan dan dapat memperoleh sertifikat atau akta nikah, hal ini berbeda dengan yang terjadi terhadap orang tanpa kewarganegaraan, dalam hukum internasional disebut sebagai Stateless person. Orang tanpa kewarganegaraan akan mengalami kesulitan dalam mengklaim hak-hak dan pelayanan di tempat mereka tinggal. Data menunjukkan bahwa 3.7 juta orang tanpa kewarganegaraan dalam 78 negara. Sementara UNCHR memperkirakan ada 10 juta orang secara global merupakan Stateless.

Umumnya terdapat beberapa faktor seseorang tidak memiliki kewarganegaraan yakni:

1. Konflik Hukum;

${ }^{1}$ Kusniati, R. (2011). Sejarah Perlindungan HakHak Asasi Manusia dalam Kaitannya dengan Konsepsi Negara Hukum. https://onlinejournal.unja.ac.id/jimih/article/view/537. 
Konflik ini terkait pembatalan kewarganegaraan. Terdapat negara-negara yang memperbolehkan warganya untuk melepaskan kewarganegaraan bahkan sebelum warga tersebut mendapatkan kewarganegaraan dari negara yang ia ajukan. Hal ini juga disebabkan konflik salah satu negara tidak memperbolehkan pembatalan suatu kewarganegaraan sebelum mendapat kewarganegaraan lain, namun disatu sisi negara dituju tersebut tidak memberikan kewarganegaraan kepada individu yang masih menyandang status kewarganegaraan asal.

2. Perubahan Wilayah Negara;

Ketika suatu negara mengalami perubahan kedaulatan maka hukum kewarganegaraannya dapat berubah diikuti dengan pelaksanaannya. Dalam keadaan ini seseorang menjadi tidak memiliki kewarganegaraan apabila mereka tidak mengajukan permohonan kewarganegaraan sesuai dengan hukum atau peraturan perundang-undangan yang berlaku.

3. Hukum Perkawinan;

Terdapat kondisi dimana beberapa negara merubah status kewarganegaraan warga negaranya, salah satu contohnya seorang perempuan ketika ia menikah dengan seorang warganegara lain, maka ia harus segera memperoleh kewarganegaraan suaminya tersebut dan apabila tidak, maka dia tidak memiliki kewarganegaraan, hal ini juga dapat berlaku kepada perempuan yang bercerai, maka ia dapat kehilangan kewarganegaraan yang diperolehnya saat ia menikah.

4. Prosedur Administrasi;

Dalam mengajukan kewarganegaraan terdapat banyak prosedur yang harus dilakukan seseorang agar permohonannya tersebut dapat dikabulkan, namun hal itu dapat menjadi kendala karena ketidakmampuan seseorang 
sehingga dia tidak dapat mengajukan permohonan kewarganegaraan.

5. Diskriminasi;

Diskriminasi dapat terjadi didasarkan suku, ras, agama, warna kulit. Pendapat politik dan faktor-faktor lain juga menjadi sebuah diskriminasi jika mengandung kata-kata yang bersifat prasangka atau jika pelaksanaan hukum tersebut mengakibatkan perlakuan diskriminatif. Hal ini menjadi salah satu sebab seseorang tidak mendapat kewarganegaraannya dari suatu negara, contohnya terhadap etnis Rohingnya di Myanmar.

6. Tidak Mempunyai Surat Kelahiran;

Perjanjian Internasional tentang Hak Sipil dan Politik dan Konvensi Hak Anak menyatakan bahwa setiap anak, dimanapun dilahirkan, harus segera didaftarkan setelah lahir. Tanpa bukti kelahiran ini, atau tanpa adanya pendaftaran kelahiran yang diakui, maka sulit bagi anak untuk menegaskan identitas diri serta memperoleh kewarganegaraan.

7. Pembatalan Kewarganegaraan Oleh Negara;

Hilangnya kewarganegaraan seseorang terjadi ketika negara membatalkan warga negara seseorang karena negara sedang melaksanakan prosedur yang diskriminatif. Tindakan ini biasanya diikuti dengan pengusiran orang tersebut. ${ }^{2}$.

Status tanpa kewarganegaraan yang dialami oleh orang-orang tertentu dapat membahayakan bahkan menghancurkan kehidupan mereka. Dan perlu diketahui, ada kelompok orang-orang tanpa status warganegara yang masuk dalam kategori refugess atau pengsungsi dan ada juga tidak.

2 Widodo Ekatjahjana. Masalah Kewarganegaraan Dan Tidak Berkewarganegaraan. Jurnal Ilmu Hukum Inovatif, Vol. 2, No. 3. 2010, hal. 107. 
Terhadap kelompok orang-orang tanpa kewarganegaraan dan termasuk pengungsi maka mereka berhak untuk mendapatkan perlindungan berdasarkan Convention Relating To The Status Of Refugees 1951. Menjawab masalah perlindungan orang tanpa kewarganegaraan ini dapat dilihat dalam Convention Relating To The Status Of Stateless Persons 1954. ${ }^{3}$

Indonesia telah memiliki instrumen hukum terhadap orang asing yaitu melalui Undang-Undang Nomor 6 Tahun 2011 tentang Keimigrasian. Di dalam Pasal 1 angka 1 UndangUndang ini mengemukakan Keimigrasian adalah hal ihwal lalu lintas orang yang masuk atau keluar wilayah Indonesia serta pengawasannya dalam rangka menjaga tegaknya kedaulatan negara. Istilah imigrasi ini berdasar dari kata migratio dari bahasa Latin yang berarti perpindahan orang dari suatu tempat atau negara menuju ke tempat atau negara lain.

Undang-Undang ini juga menggunakan istilah Orang Asing, yakni orang yang bukan merupakan warga negara Indonesia. Gatot Supramono dalam bukunya menjelaskan bahwa orang asing dapat diberi pengertian, yaitu orang yang bukan wargan negara Indonesia dan sedang berada di Indonesia. Pengertian orang asing termasukpula badan hukum asing yaitu badan hukum yang didirikan berdasarkan hukum asing. ${ }^{4}$

Berbeda dengan hukum Internasional yang telah mengakui orang tanpa kewarganegaraan, hukum nasional yang berlaku di Indonesia tidak mengenal istilah ini. Hal ini ditegaskan pada penjelasan Undang-Undang Nomor 12 Tahun 2006 tentang Kewarganegaraan, yang mengemukakan bahwa Undang-Undang ini tidak mengenal kewarganegaraan ganda

${ }^{3}$ UNHCR. Melindungi Hak-Hak Orang-Orang Tanpa Kewarganegaraan. 2010. hal. 1

4 Gatot Supramono. Hukum Orang Asing di Indonesia. Sinar Grafika. Jakarta. 2012. hal. 4-5. 
(bipatride) ataupun tanpa kewarganegaraan (apatride). Namun Undang-Undang ini memperhatikan asas-asas yang kewarganegaraan umum dan berlaku universal.

Asas-asas yang dianut dalam Undang-Undang ini adalah:

1. Asas ius sanguinis (law of the blood) adalah asas yang menentukan kewarganegaraan seseorang berdasarkan keturunan, bukan berdasarkan negara tempat kelahiran.

2. Asas ius soli (law of the soil) secara terbatas adalah asas yang menentukan kewarganegaraan seseorang berdasarkan negara tempat kelahiran, yang diberlakukan terbatas bagi anak-anak sesuai dengan ketentuan yang diatur dalam Undang-Undang ini.

3. Asas kewarganegaraan tunggal adalah asas yang menentukan satu kewarganegaraan bagi setiap orang.

4. Asas kewarganegaraan ganda terbatas adalah asas yang menentukan kewarganegaraan ganda bagi anak-anak sesuai dengan ketentuan yang diatur dalam UndangUndang ini.

Tindak lanjut pelaksanaan Undang-Undang Kewarganegaraan dituangkan dalam Peraturan Pemerintah Republik Indonesia Nomor 2 Tahun 2007 tentang Tata Cara Memperoleh, Kehilangan, Pembatalan, dan Memperoleh Kembali Kewarganegaraan Republik Indonesia. Akan tetapi, Peraturan Pemerintah ini tidak mengatur mengenai hak orang tanpa kewarganegaraan dalam memperoleh kewarganegaraan Indonesia dikarekan dapat dilihat pada tiap persyaratan memuat tentang asal kewarganegaraan dari pemohon kewarganegaraan Indonesia.

Hasil review dan diskusi dengan cara penilaian kuesioner oleh akademisi, LSM, dan instansi pemerintah yang berada di Indonesia diketahui bahwa orang tanpa kewarganegaraan terdiri atas:

1. Etnis Indonesia Cina yang tidak memiliki dokumen untuk membuktikan kewarganegaraan Indonesia, karena status 
kewarganegaraannya tercatat secara salah dalam dokumen registrasi sipil mereka dan mereka yang tidak dikenal sebagai warga negara Cina maupun Indonesia;

2. Etnis Arab dan India yang tidak memiliki dokumen untuk membuktikan kewarganegaraan mereka atau status kewarganegaraan mereka tercatat secara salah dalam dokumen registrasi sipil mereka;

3. Pekerja migran Indonesia yang kehilangan kewarganegaraannya berdasarkan Undang-Undang Tahun 1958 tentang ketentuan tinggal di luar negeri yang diperpanjang dan tidak dapat memperoleh kewarganegaraan berdasarkan Undang-Undang tahun 2006;

4. Sejumlah kecil orang Indonesia yang diasingkan keluar Indonesia karena pada saat ia terkait konflik politik di tahun 1965 dan menjadi tanpa kewarganegaraan;

5. Orang lainnya yang menjadi Stateless karena tergolong sebagai migrant tanpa dokumen dari Cina, yang telah lama tinggal di Indonesia. Kelompok ini bermigrasi ke Indonesia tapi tidak memiliki kewarganegaraan Indonesia karena mereka tidak lahir di Indonesia5.

Penanganan terhadap orang tanpa kewarganegaraan yang berada di Indonesia dilakukan oleh pihak imigrasi Indonesia dengan cara yang sama terhadap deteni pada umumnya, yaitu di detensi pada ruang detensi imigrasi atau rumah detensi imigrasi (rudenim). Pengertian detensi tidak dijelaskan dalam Undang-Undang Keimigrasian, namun mengacu pada pasal 83 ayat 1 yang mengemukakan "Pejabat imigrasi berwenang menempatkan Orang Asing dalam Rumah Detensi Imigrasi atau Ruang Detensi Imigrasi", dapat ditarik kesimpulan menurut pasal 1 angka 35 Deteni adalah Orang

${ }^{5}$ https://www.unhcr.org/id/orang-orang-tanpa-kewarganegaraan 
Asing penghuni Rumah Detensi Imigrasi atau Ruang Detensi Imigrasi yang telah mendapatkan keputusan pendetensian dari Pejabat Imigrasi.

Hal-hal mengenai penanganan orang tanpa kewarganegaran di wilayah hukum Indonesia, penjaminan hak-hak deteni tanpa kewarganegaraan selama di detensi oleh pihak imigrasi, hingga kepastian hukum orang tanpa kewarganegaraan setelah di detensi telah diatur sedemikian rupa dalam Convention Relating to The Status of Stateless Persons 1954 namun tidak di hukum nasional Indonesia.

\section{B. Pembahasan}

Dalam hukum internasional dan hukum nasional Indonesia, perlu diketahui bahwa hukum internasional dan hukum nasional adalah 2 (dua) jenis hukum yang berbeda. Hukum nasional adalah hukum yang berlaku secara ekslusif dalam wilayah suatu negara yang berdaulat. Sedangkan hukum internasional, pada dasarnya ditujukan untuk mengatur hubungan negara-negara pada tataran internasional .

Ada beberapa perbedaan-perbedaan yang menonjol antara hukum internasional dengan hukum nasional.Pertama, dalam hukum internasional negara dianggap sebagai objek utama dari pengaturan. Sedangkan hukum nasional lebih menekankan pada pengaturan hubungan antar individu dengan individu dan negara dalam wilayah yuridik dari masing-masing negara. Yang kedua yaitu dengan membedakan bentuk hukum, dalam hukum internasional tidak terdapat badan legislatif, eksekutif, dan yudikatif. Terakhir, hal yang sangat menonjol adalah prinsip hukum internasional didasarkan pada prinsip persamaan negara sebagai subjek hukum. Prinsip ini tidak menonjol dalam hukum nasional yang serba tersentralisir.

Pada hukum internasional dan hukum nasional dapat disejajarkan sebagai kesatuan hukum dan dapat pula 
diposisikan sebagai 2 (dua) entitas hukum yang berbeda. Kedua pemahaman ini tentunya menciptakan 2 (dua) pandangan yang berbeda. Sejajarnya hukum internasional dan hukum nasional menimbulkan pandangan bahwa hukum nasional diatas hukum internasional. Sedangkan pembedaan antara hukum internasional dengan hukum nasional menimbulkan pandangan bahwa hukum internasional bergantung pada keberlakuannya di hukum nasional melalui penerimaan suatu negara.

Mengenai kedudukan hukum internasional pada hukum nasional tidak terlepas dari teori berlakunya hukum internasional kedalam hukum nasional, yaitu teori inkorporasi dan teori transformasi. Teori inkorporasi merupakan lanjutan dari pandangan monisme yang menganggap hukum internasional dan hukum nasional adalah kesatuan yang tunggal. Oleh karena itu teori inkorporasi memandang hukum internasionl adalah bagian dari hukum nasional dan berlakunya hukum internasional dalam sistem hukum nasional tidak membutuhkan persetujuan legislasi terlebih dahulu tetapi dengan sendirinya berlaku . Selanjutnya, teori transformasi adalah lanjutan dari pemikiran bahwa hukum internasional dan hukum nasional merupakan dua jenis hukum yang berbeda dan berdiri sendiri. Teori transformasi berarti berlakunya hukum internasional dalam hukum nasional harus terlebih dahulu dengan persetujuan badan legislatif negara .

Selain dua hal tersebut, negara diam-diam telah mengakui keberadaan prinsip hukum internasional serta mengadopsi prinsip hukum internasional melalui sistem hukum nasional.Indonesia sebagai bagian dari masyarakat internasional mengakui supremasi hukum internasional, namun tidak secara langsung menerimanya dengan tunduk pada hukum internasional. Dalam hal perjanjian internasional, berdasarkan pertimbangan huruf d Undang-Undang Nomor 24 
Tahun 2000 Tentang Perjanjian Internasional yang mengemukakan :

bahwa pembuatan dan pengesahan perjanjian internasional antara Pemerintah Republik Indonesia dan pemerintah negara-negara lain, organisasi internasional, dan subjek hukum internasional lain adalah suatu perbuatan hukum yang sangat penting karena mengikat negara pada bidang-bidang tertentu, dan oleh sebab itu pembuatan dan pengesahan suatu perjanjian internasional harus dilakukan dengan dasardasar yang jelas dan kuat, dengan menggunakan instrumen peraturan perundang-undangan yang jelas pula.

Pada Pasal 1 angka 2 Undang-Undang Perjanjian Internasional, yang dimaksud Pengesahan adalah perbuatan hukum untuk pengikatkan diri pada suatu perjanjian internasional dalam bentuk ratifikasi (ratification), aksesi (accession), penerimaan (acceptance) dan penyetujuan (approval).

1) Ratifikasi (ratification), yaitu apabila negara yang akan mengesahkan suatu perjanjian internasional turut menandatangani naskah perjanjian internasional;

2) Aksesi (accesion), yaitu apabila negara yang akan mengesahkan suatu perjanjian internasional tidak turut menandatangani naskah perjanjian;

3) Penerimaan (acceptance) atau penyetujuan (approval) yaitu pernyataan menerima atau menyetujui dari negaranegara pihak pada suatu perjanjian intemasional atas perubahan perjanjian internasional tersebut; dan

4) perjanjian-perjanjian intemasional yang sifatnya selfexecuting (langsung berlaku pada saat penandatanganan).

Menurut pasal 9 ayat 2 Undang-Undang Perjanjian Internasional, pengesahan perjanjian internasional sebagaimana yang dimaksud pada ayat (1) dilakukan dengan undang-undang atau keputusan presiden. Lalu pada 
penjelasan pada pasal yang sama, menegaskan bahwa Pengesahan dengan undang-undang memerlukan persetujuan Dewan Perwakilan Rakyat. Pengesahan dengan keputusan presiden selanjutnya diberitahukan kepada Dewan Perwakilan Rakyat.

Mengenai pengesahan melalui undang-undang, diatur pada pasal 10 Undang-Undang Perjanjian Internasional yang menegaskan bahwa Pengesahan perjanjian internasional dilakukan dengan undang-undang apabila berkenaan dengan :

1. masalah politik, perdamaian, pertahanan, dan keamanan negara;

2. perubahan wilayah atau penetapan batas wilayah negara Republik Indonesia;

3. kedaulatan atau hak berdaulat negara;

4. hak asasi manusia

5. dan lingkungan hidup;

6. pembentukan kaidah hukum baru;

7. pinjaman dan/atau hibah luar negeri.

Sedangkan pengesahan selain daripada undangundang dilakukan melalui keputusan presiden. Ketentuan pengesahan melalui keputusan presiden berdasarkan pasal 11 ayat 1 Undang-Undang Perjanjian Internasional adalah Pengesahan perjanjian melalui keputusan presiden dilakukan atas perjanjian yang mensyaratkan adanya pengesahan sebelum memulai berlakunya perjanjian, tetapi memiliki materi yang bersifat prosedural dan memerlukan penerapan dalam waktu singkat tanpa mempengaruhi peraturan perundang-undangan nasional. Jenis-jenis perjanjian yang termasuk dalam kategori ini, di antaranya adalah perjanjian induk yang menyangkut kerja sama di bidang ilmu pengetahuan dan teknologi, ekonomi, teknik, perdagangan, kebudayaan, pelayaran niaga, penghindaran pajak berganda dan kerja sama perlindungan penanaman modal, serta pengesahan yang bersifat teknis. 
Berdasarkan uraian diatas, dapat diketahui bahwa Indonesia tidak memandang bahwa hukum internasional tidak dapat berlaku secara langsung di Indonesia. Namun berlakunya hukum internasional di Indonesia didasari oleh keterikatannya sebagai bagian dari masyarakat Internasional. Perjanjian internasional harus diubah menjadi hukum nasional dalam bentuk melalui proses ratifikasi peraturan perundangundangan. Perjanjian internasional sesuai dengan UU Nomor 24 tahun 2000 tentang Perjanjian Internasional, diratifikasi melalui undang-undang dan keputusan presiden( Berdasarkan UU Nomor 12 tahun 2011 tentang Pembentukan Peraturan Perundang-undangan, Pasal 7 Ayat (1) huruf e, menyebutkan bahwa keputusan presiden diubah menjadi peraturan presiden). Namun tidak serta merta menjadi hukum nasional, Undang-Undang ini hanya menjadikan Indonesia sebagai negara terikat. Oleh karena itu diperlukan pengaturan yang lebih khusus mengenai perjanjian internasional yang akan diratifikasi.

Instrumen hukum internasional yang mengatur tentang orang tanpa kewarganegaraan (Stateless person) adalah Convention Relating To The Status Of Stateless Persons. Baik pengungsi (refugees) dan orang tanpa kewarganegaraan (Stateless person) tidak dibedakan awalnya dikarenakan keduanya sama-sama mendapatkan bantuan dari organisasi pengungsi internasional. Setelah terjadinya Perang Dunia II, terdapat berbagai masalah tentang Statelessness atau keadaan tanpa kewarganegaraan yang dihadapi masyarakat internasional. PBB berkomitmen untuk menjamin terlaksananya hak dan kebebasan orang tanpa kewarganegaraan (Stateless person). Hak dan kebebasan yang dibahas dalam konvensi ini yaitu masalah status hukum, 
pekerjaan, dan kesejahteraan ${ }^{6}$. Sehingga dengan meningkatnya status hukum Stateless person mampu membuat orang tanpa kewarganegaraan (Stateless person) bukan penungsi mendapatkan perlindungan hukum secara internasional.

Berdasarkan Convention Relating To The Status of Stateless Persons, berikut ini ada beberapa pasal yang berkaitan dengan hak dan kebebasan orang tanpa kewarganegaraan (Stateless person) :

1) Personal Status (Pasal 12)

2) Movable and Immovable property (Pasal 13)

3) Artistic Rights and Industrial Propertyx (Pasal 14)

4) Right of Association (Pasal 15)

5) Access to Courts (Pasal 16)

6) Wage-earning employment (Pasal 17)

7) Self Employment (Pasal 18)

8) Liberal Professions (Pasal 19)

9) Rationing (Pasal 20)

10) Housing (Pasal 21)

11) Public Education (Pasal 22)

12) Public Relief (Pasal 23)

13) Labour legislation and social security (Pasal 24)

Selain hak dan kebebasan orang tanpa kewarganegaraan, konvensi ini juga mengatur tentang tindakan administrasi negara peserta terhadap orang tanpa kewarganegaraan pada pasal 25-32, berikut ketentuannya:

1) Administrative assistance (Pasal 25)

2) Freedom of movement (Pasal 26)

3) Identity papers (Pasal 27)

4) Travel documents (Pasal 28)

5) Fiscal charges (Pasal 29)

${ }^{6}$ Asih Saraswati. Convention Relating to the Status of Stateless Persons. Jurnal Hukum Internasional, Vol. 2 No. 1, 2004. hal. 186 
6) Transfer of assets (Pasal 30)

7) Expulsion (Pasal 31)

8) Naturalization (Pasal 32)

Penjelasan dari pasal-pasal tersebut terdapat dalam Convention Relating To The Status Of Stateless Persons, berikut ini ada beberapa pasal yang berkaitan dengan hak dan kebebasan orang tanpa kewarganegaraan (Stateless person) :

"Chapter II : Juridicial Status"

"Article 12personal status"

1. "The personal status of a Stateless person shall be governed by the law of the country of his domicile or, if he has no domicile, by the law of the country of his residence."

2. "Rights previously acquired by a Stateless person and dependent on personal status, more particularly rights attaching to marriage, shall be respected by a Contracting State, subject to compliance, if this benecessary, with the formalities required by the law of that State, provided that the right in question is one which would have been recognized by the law of that State had he not become Stateless."

\section{"Article 13 movable and immovable property"}

"The Contracting States shall accord to a Stateless person treatment as favourable as possible and, in any event, not less favourable than that accorded to aliens generally in the same circumstances, as regards the acquisition of movable and immovable property and other rights pertaining thereto, and to leases and other contracts relating to movable and immovable property."

"Article 14 artistic rights and industrial property"

"In respect of the protection of industrial property, such as inventions, designs or models, trade marks, trade names, and of rights in literary, artistic and scientific works, a Stateless person shall be accorded in the country in which he has his habitual residence the same protection as is accorded to nationals of that country. In the territory of any other Contracting State, he shall be 
accorded the same protection as is accorded in that territory to nationals of the country in which he has his habitual residence."

\section{"Article 15 right of association"}

"As regards non-political and non-profit-making associations and trade unions the Contracting States shall accord to Stateless persons lawfully staying in their territory treatment as favourable as possible, and in any event, not less favourable than that accorded to aliens generally in the same circumstances."

\section{"Article 16 access to courts"}

1. "A Stateless person shall have free access to the Courts of Law on the territory of all Contracting States."

2. "A Stateless person shall enjoy in the Contracting State in which he has his habitual residence the same treatment as a national in matters pertaining to access to the Courts, including legal assistance and exemption from cautio judicatum solvi."

3. "A Stateless person shall be accorded in the matters referred to in paragraph 2 in countries other than that in which he has his habitual residence the treatment granted to a national of the country of his habitual residence."

"Chapter IV : Gainful Employment"

"Article 17 wage-earning employment"

"The Contracting States shall accord to Stateless persons lawfully staying in their territory treatment as favourable as possible and, in any event, not less favourable than that accorded to aliens generally in the same circumstances, as regards the right to engage in wage-earning employment."

1. "The Contracting States shall give sympathetic consideration to assimilating the rights of all Stateless persons with regard to wage-earning employment to those of nationals, and in particular of those Stateless persons who have entered their territory pursuant to programmes 
of labour recruitment or under immigration schemes."

\section{"Article 18 self-employment"}

"The Contracting States shall accord to a Stateless person lawfully in their territory treatment as favourable as possible and, in any event, not less favourable than that accorded to aliens generally in the same circumstances, as regards the right to engage on his own account in agriculture, industry, handicrafts and commerce and to establish commercial and industrial companies."

\section{"Article 19 liberal professions"}

"Each Contracting State shall accord to Stateless persons lawfully staying in their territory who hold diplomas recognized by the competent authorities of that State, and who are desirous of practising a liberal profession, treatment as favourable as possible and, in any event, not less favourable than that accorded to aliens generally in the same circumstances."

"Chapter IV : Welfare"

"Article 20 rationing"

"Where a rationing system exists, which applies to the population at large and regulates the general distribution of products in short supply, Stateless persons shall be accorded the same treatment as nationals."

"Article 21 housing"

"As regards housing, the Contracting States, in so far as the matter is regulated by laws or regulations or is subject to the control of public authorities, shall accord to Stateless persons lawfully staying in their territory treatment as favourable as possible and, in any event, not less favourable than that accorded to aliens generally in the same circumstances."

"Article 22 public education" 
1. "The Contracting States shall accord to Stateless persons the same treatment as is accorded to nationals with respect to elementary education."

2. "The Contracting States shall accord to Stateless persons treatment asfavourable as possible and, in any event, not less favourable than that accorded to aliens generally in the same circumstances, with respect to education other than elementary education and, in particular, as regards access to studies, the recognition of foreign school certificates, diplomas and degrees, the remission of fees and charges and the award of scholarships."

\section{"Article 23 public relief"}

"The Contracting States shall accord to Stateless persons lawfully staying in their territory the same treatment with respect to public relief and assistance as is accorded to their nationals."

\section{"Article 24 labour legislation and social security"}

1. "The Contracting States shall accord to Stateless persons lawfully staying in their territory the same treatment as is accorded to nationals in respect of the following matters:

a. "In so far as such matters are governed by laws or regulations or are subject to the control of administrative authorities: remuneration, including family allowances where these form part of remuneration, hours of work, overtime arrangements, holidays with pay, restrictions on homework, minimum age of employment, apprenticeship and training, women's work and the work of young persons, and the enjoyment of the benefits of collective bargaining;

b. "Social security (legal provisions in respect of employment, injury, occupational diseases, maternity, sickness, disability, old age, death, unemployment, family responsibilities and any other contingency which, according to national laws or regulations, is covered by a social 
security scheme), subject to the following limitations:

(i) There may be appropriate arrangements for the maintenance of acquired rights and rights in course of acquisition;

(ii) National laws or regulations of the country of residence may prescribe special arrangements concerning benefits or portions of benefits which are payable wholly out of public funds, and concerning allowances paid to persons who do not fulfil the contribution conditions prescribed for the award of a normal pension.

2. "The right to compensation for the death of a Stateless person resultingfrom employment injury or from occupational disease shall not be affected by the fact that the residence of the beneficiary is outside the territory of the Contracting State."

3. "The Contracting States shall extend to Stateless persons the benefits ofagreements concluded between them, or which may be concluded between them in the future, concerning the maintenance of acquired rights and rights in the process of acquisition in regard to social security, subject only to the conditions which apply to nationals of the States signatory to the agreements in question."

4. "The Contracting States will give sympathetic consideration to extending to Stateless persons so far as possible the benefits of similar agreements which may at any time be in force between such Contracting States and non-contracting States."

Selain hak dan kebebasan orang tanpa kewarganegaraan (Stateless persons), konvensi ini juga mengatur tentang tindakan administrasi negara peserta terhadap orang tanpa kewarganegaraan (Stateless person) pada pasal 25 - 32. Berikut ini adalah ketentuannya :

"Chapter V: Administrative Measures" 


\section{"Article 25 administrative assistance"}

1. "When the exercise of a right by a Stateless person would normally require the assistance of authorities of a foreign country to whom he cannot have recourse, the Contracting State in whose territory he is residing shall arrange that such assistance be afforded to him by their own authorities."

2. "The authority or authorities mentioned in paragraph 1 shall deliver or cause to be delivered under their supervision to Stateless persons such documents or certifications as would normally be delivered to aliens by or through their national authorities."

3. "Documents or certifications so delivered shall stand in the stead of the official instruments delivered to aliens by or through their national authorities and shall be given credence in the absence of proof to the contrary."

4. "Subject to such exceptional treatment as may be granted to indigent persons, fees may be charged for the services mentioned herein, but such fees shall be moderate and commensurate with those charged to nationals for similar services."

5. "The provisions of this article shall be without prejudice to articles 27 and 28."

"Article 26 freedom of movement"

"Each Contracting State shall accord to Stateless persons lawfully in its territory the right to choose their place of residence and to move freely within its territory, subject to any regulations applicable to aliens generally in the same circumstances."

"Article 27 identity papers"

The Contracting States shall issue identity papers to any Stateless person in their territory who does not possess a valid travel document."

"Article 28 travel documents"

"The Contracting States shall issue to Stateless persons lawfully staying in their territory travel documents for the purpose of travel outside their territory, unless 
compelling reasons of national security or public order otherwise require, and the provisions of the Schedule to this Convention shall apply with respect to such documents. The Contracting States may issue such a travel document to any other Stateless person in their territory; they shall in particular give sympathetic consideration to the issue of such a travel document to Stateless persons in their territory who are unable to obtain a travel document from the country of their lawful residence."

"Article 29 fiscal charges"

1. "The Contracting States shall not impose upon Stateless persons duties, charges or taxes, of any description whatsoever, other or higher than those which are or may be levied on their nationals in similar situations."

2. "Nothing in the above paragraph shall prevent the application to Stateless persons of the laws and regulations concerning charges in respect of the issue to aliens of administrative documents including identity papers."

\section{"Article 30 transfer of assets"}

1. "A Contracting State shall, in conformity with its laws and regulations, permit Stateless persons to transfer assets which they have brought into its territory, to another country where they have been admitted for the purposes of resettlement."

2. "A Contracting State shall give sympathetic consideration to the application of Stateless persons for permission to transfer assets wherever they may be and which are necessary for their resettlement in another country to which they have been admitted."

\section{"Article 31 expulsion"}

1. "The Contracting States shall not expel a Stateless person lawfully in their territory save on grounds of national security or public order."

2. "The expulsion of such a Stateless person shll be only in pursuance of a decision reached in accordance with due process of law. Except where compelling 
reasons of national security otherwise require, the Stateless person shall be allowed to submit evidence to clear himself, and to appeal to and be represented for the purpose before competent authority or a person or persons specially designated by the competent authority."

3. "The Contracting States shall allow such a Stateless person a reasonable period within which to seek legal admission into another country. The Contracting States reserve the right to apply during that period such internal measures as they may deem necessary."

\section{"Article 32 naturalization"}

"The Contracting States shall as far as possible facilitate the assimilation andnaturalization of Stateless persons. They shall in particular make every effortto expedite naturalization proceedings and to reduce as far as possible thecharges and costs of such proceedings."

Dengan adanya konvensi ini, diharapkan menjadi pedoman bagi pemerintah Indonesia, melalui Kementerian Hukum dan Hak Asasi Manusia (Kemenkumham) khususnya Direktorat Jenderal Imigrasi terhadap penanganan orang tanpa kewarganegaraan bukan pengungsi di Indonesia.

Hukum Internasional yang mengatur tentang orang tanpa kewarganegaraan (Stateless person) secara spesifik adalah Convention Relating To The Status Of Stateless Persons. Namun sebagai negara yang berdaulat, Indonesia juga memiliki hak untuk menyatakan terikat atau tidak dengan konvensi internasional manapun. Hubungan denganadanyaaktivitasmasuknyawarga Negara Asingkesuatu Negara tertentubahwa Hukum Internasional memberikan hak dan wewenang kepada semua negara untuk menjalankan 
yurisdiksi atas orang dan benda serta perbuatan yang terjadi di dalam wilayah negara tersebut.7

Indonesia tidak meratifikasi Convention Relating To The Status of Stateless Person, karena Undang-Undang Kewarganegaraan menegaskan pada dasarnya tidak mengenal tanpa kewarganegaraan (apatride) atau Stateless. Namun, pada kenyataannya kasus orang tanpa kewarganegaraan (Stateless person) tersebut ada di Indonesia, konsekuensi hukum yang timbul adalah mereka akan didetensi oleh pihak imigrasi.

Seperti kasus yang dialami oleh seorang deteni Statelessberikut yaitu, Danko Nizar Zlavic alias Nizar Mark adalah deteni yang mengaku berkewarganegaraan Kroasia yang masuk ke wilayah Indonesia dengan tidak memiliki dokumen keimigrasian ${ }^{8}$. Hal ini dimulai ketika ia diberikan Tindakan Keimigrasian di Bali pada tahun berupa "karantina" atau detensi saat ini. Hal ini terjadi karena ia tidak dapat menunjukkan dokumen perjalanan atau dokumen keimigrasiannya. Pada saat itu, pendetensian Zlavic telah sah menurut hukum berdasarkan Pasal 44 Ayat (1), UndangUndang Nomor 9 Tahun 1992 Tentang Keimigrasian yang mengemukakan Setiap orang asing yang berada di Wilayah Indonesia dapat ditempatkan di Karantina Imigrasi:

a. Apabila berada di Wilayah Indonesiatanpa memiliki izin keimigrasian Yang sah;

b. Dalam rangka menunggu proses pengusiran atau deportasi ke luar wilayah Indonesia.

${ }^{7}$ A. Amrullah Armansyah, dkk. Penegakan Hukum Keimigrasian Terhadap Warga Negara Asing Anak Buah Kapal (Abk) Tangkap Ikan SecaraI legal. Pleno Jure, Vol. 9. 2019. hal. 19

8 M. Alvi Syahrin. Penerapan Hukum Deteni Tanpa Kewarganegaraan (Stateless) yang Ditahan Lebih Dari 10 (Sepuluh) Tahun di Rumah Detensi Imigrasi Jakarta: Studi Kasus Danko Nizar Zlavic. Jurnal Fiat Justicia, Vol. 3, No. 2. 2017. hal. 475. 
Lalu pada tahun 2002 Zlavic dipindahkan ke Rudenim Jakarta. Berdasarkan pengakuan dari Zlavic, pihak Rudenim Jakarta mencoba menghubungi perwakilan negara Kroasia yang sesuai dengan pasal 3 ayat 2 Peraturan Direktur Jenderal Tahun 2006 tentang Tata Cara Pendetensian Orang Asing yang mengemukakan Deteni yang telah ditempatkan di Rumah Detensi Imigrasi, Kepala Rumah Detensi Imigrasi wajib memberitahukan kepada perwakilan negara yang bersangkutan dalam rangka proses pemulangan atau pendeportasian/pengusiran dengan tembusan kepada Direktur Jenderal Imigrasi Up. Direktur Penyidikan dan Penindakan Keimigrasian dan Kepala Divisi Keimigrasian yang meliputi wilayah kerja Rumah Detensi Imigrasi yang bersangkutan.

Pihak perwakilan negara Kroasia tidak mengakui Zlavic sebagai warga negara Kroasia karena tidak memiliki bukti yang mendukung atau bukti tertulis yang menyatakan bahwa ia adalah warga negara Kroasia. Pihak Rudenim juga mencoba menyurati kebeberapa negara seperti Serbia dan Bosnia dan Herzegovina, sesuai saran dari pihak perwakilan negara Kroasia, namun hasilnya pun sama dengan Kroasia9.

Dikarenakan tidak ada negara manapun yang mengakui, maka Danko Nizar Zlavic ditetapkan sebagai Deteni Stateless oleh pihak Rudenim. Pada tahun 2017 Zlavic menderita sakit dan meninggal dunia saat menjalani rawat inap akibat sakit yang dideritanya dengan masih berstatuskan sebagai seorang deteni dan status kewarganegaraan yang masih belum diketahui. ${ }^{10}$

9 Ibid, hal. 476

10 Agung Sulistyo Purnomo. Pandangan Hak Asasi Manusia terhadap Pembiaran Orang dengan Status 'Stateless' di Indonesia (Studi Kasus: Danko Nizar Zlavic). Jurnal Ilmiah Kajian Keimigrasian, Vol. 2, No. 1, 2019, hal. 96. 
Sedangkan pada kasus Sajjad Yaqub dan keluarganya, mereka adalah pencari suaka yang berasal dari Afganistan. Para pencari suaka ini terpaksa keluar dari negaranya akibat konflik berkepanjangan yang disebabkan oleh Taliban. Mereka berencana untuk pergi ke Australia dengan transit ke Indonesia. Namun naas mereka terdampar di Sumbawa Barat dan menjadi deteni disana. Pendetensian Sajjad Yaqub dan keluarganya juga telah sesuai dengan Pasal 44 Ayat (1) Undang-Undang Nomor 9 Tahun 1992 Tentang Keimigrasian yang mengemukakan Setiap orang asing yang berada di Wilayah Indonesia dapat ditempatkan di Karantina Imigrasi:

1. Apabila berada di Wilayah Indonesia tanpa memiliki izin keimigrasian Yang sah;

2. Dalam rangka menunggu proses pengusiran atau deportasi ke luar wilayah Indonesia.

Selama 20 tahun itu, keluarga Sajjad harus tinggal di Rumah Detensi Imigran (Rudenim). Selama 13 tahun, ia ber mukim di Sumbawa, Nusa Tenggara Barat; dan 7 Tahun di Kota Manado, Sulawesi Utara ${ }^{11}$. Sajjad Bersama dengan pamannya, Muhammad Rahim melakukan aksi bakar diri. Hal ini terjadi pasca penutupan kasus penutupan kasus (case closed) yang dilakukan oleh UNHCR pada awal Februari 2019 lalu12. Hal ini menyebabkan keduanya meninggal dunia akibat luka bakar.

Pada kasus Sajjad Yaqub beserta keluargnya, berdasarkan pasal 1 angka 8 Peraturan Direktorat Jenderal Imigrasi Nomor IMI-0352.GR.02.07 Tentang Penanganan Imigran Ilegal Yang Menyatakan Diri Sebagai Pencari Suaka Atau Pengungsi yang mengemukakan Orang Asing Yang

11 https://kumparan.com/manadobacirita-admin/duka-pencarisuaka-20-tahun-tanpa-kewarganegaraan-disetopnya-bantuan1550307880236333677

12 https://utamanews.com/sosial-budaya/Dilema-10-WNAfghanistan-di-Manado--Bagaimana-Statusnya-Saat-ini- 
Permohonan Status Pengungsinya Ditolak (Final Rejected Person) adalah pencari suaka yang permohonan status pengungsinya ditutup (case closed) oleh UNHCR, dan tidak bisa mengajukan banding. Hal ini menyebabkan Sajjad Yaqub dan keluargnya menjadi orang tanpa kewarganegaraan (Stateless person).

Yang menjadi pokok permasalahan terhadap penanganan orang tanpa kewarganegaraan (Stateless person) bukan pengungsi di Indonesia adalah ketika dalam proses pendetensiannya. Orang tanpa kewarganegaraan seharusnya tidak ditahan (didetensi). Individu yang tanpa kewarganegaraan sering kekurangan dokumen identitas, seperti kartu identitas atau paspor, yang dapat menunjukkan identitas diri mereka. Bahkan jika negara bekas kediamannya telah diidentifikasi, seringkali itu negara tidak akan segera menerima pendaftaran kembali individu tersebut. Dalam situasi ini, pendetensian harus dihindari dan hanya dilakukan jika secara jelas berdasarkan undang-undang nasional yang sesuai dengan hukum hak asasi manusia internasional. Alternatif untuk penahanan harus dieksplorasi terlebih dahulu, kecuali jika ada bukti yang menunjukkan bahwa alternatif tidak akan efektif untuk individu yang bersangkutan ${ }^{13}$.

Detensi orang tanpa kewarganegaraan (Stateless person) sebaiknya dihindari dikarenakan sudah pasti melanggar pasal 83 ayat 1 Undang-Undang Keimigrasian yang mengemukakan Pejabat Imigrasi berwenang menempatkan Orang Asing dalam Rumah Detensi Imigrasi atau Ruang Detensi Imigrasi jika Orang Asing tersebut:

a. berada di Wilayah Indonesia tanpa memiliki Izin Tinggal yang sah atau memiliki Izin Tinggal yang tidak berlaku lagi;

13 Marilyn Achiron. Nationality and Statelessness: A Handbook for Parliamentarians, Centrales de Lausanne, Switzerland, 2005, hal. 21

Uti Possidetis: Journal of International Law, Vol. 1, No. 3 (2020) 
b. berada di Wilayah Indonesia tanpa memiliki Dokumen Perjalanan yang sah;

c. dikenai Tindakan Administratif Keimigrasian berupa pembatalan Izin Tinggal karena melakukan perbuatan yang bertentangan dengan peraturan perundang-undangan atau mengganggu keamanan dan ketertiban umum;

d. menunggu pelaksanaan Deportasi; atau

e. menunggu keberangkatan keluar Wilayah Indonesia karena ditolak pemberian Tanda Masuk.

Pendetensian itu diperbolehkan jika memang tidak ada alternatif lain, dan pendetensian tersebut telah sesuai dengan kebijakan pemerintah Indonesia dibidang imigrasi yangmenganut prinsip selective policy yaitu suatu kebijakan berdasarkan prinsip selektif ${ }^{14}$. Dimana hanya orang-orang asing yang bermanfaat bagi kesejahteraan rakyat, bangsa dan Negara Republik Indonesia, dan tidak membahayakan keamanan dan ketertiban serta tidak bermusuhan dengan rakyat dan Negara berdasarkan Pancasila dan UUD Tahun 1945.

Selain itu juga sesuai dengan prinsip-prinsip dari Working Group on Arbitary Detention UNHCR yaitu :

Prinsip 1

Seorang pencari suaka atau imigran, ketika ditahan untuk diinterogasi di perbatasan, atau di dalam wilayah nasional dalam kasus masuk secara ilegal, harus diberi tahu setidaknya secara lisan, dan dalam bahasa yang dia pahami, tentang alasan dan dasar untuk keputusan menolak masuk di perbatasan, atau izin untuk tinggal sementara di wilayah, yang sedang dipertimbangkan sehubungan dengan orang yang bersangkutan.

Prinsip 2

14 A. Amrullah Armansyah, dkk, Op. Cit, hal. 19-20

Uti Possidetis: Journal of International Law, Vol. 1, No. 3 (2020) 
Setiap pencari suaka atau imigran harus memiliki kemungkinan, selama dalam ditahan, untuk berkomunikasi dengan dunia luar, termasuk melalui telepon, faks atau surat elektronik, dan untuk menghubungi pengacara, perwakilan konsuler dan kerabat.

Prinsip 3

Setiap pencari suaka atau imigran yang ditempatkan di tahanan harus segera dibawa ke pengadilan atau otoritas lainnya.

Prinsip 4

Setiap pencari suaka atau imigran, ketika ditempatkan dalam penahanan, harus memasukkan tanda tangannya dalam register yang diberi nomor dan terikat, atau memberikan jaminan yang setara, yang menunjukkan identitas orang tersebut, dasar untuk hak asuh dan otoritas yang berwenang yang memutuskan mengukur, serta waktu dan tanggal masuk dan keluar dari penahanan.

\section{Prinsip 5}

Setiap pencari suaka atau imigran, setelah masuk ke pusat penampungan, harus diberi tahu tentang peraturan internal dan, jika memungkinkan, tentang peraturan disiplin yang berlaku dan kemungkinan dia ditahan tanpa dapat berkomunikasi dengan orang lain, serta jaminan yang menyertai tindakan tersebut.

Prinsip 6

Keputusan harus diambil oleh otoritas yang diberdayakan dengan tingkat tanggung jawab yang memadai dan harus didasarkan pada kriteria legalitas yang ditetapkan oleh hukum.

Prinsip 7 
Jangka waktu maksimum harus ditetapkan oleh hukum dan penahanan dalam hal apa pun tidak boleh tidak terbatas atau dalam jangka waktu yang berlebihan.

Prinsip 8

Pemberitahuan tentang tindakan penahanan harus diberikan secara tertulis, dalam bahasa yang dipahami oleh pencari suaka atau imigran, dengan menyebutkan alasan tindakan tersebut; Undang-undang tersebut harus menetapkan syarat-syarat di mana pencari suaka atau imigran harus dapat mengajukan pemulihan kepada otoritas yudisial, yang harus segera memutuskan keabsahan tindakan tersebut dan, jika sesuai, memerintahkan pembebasan orang yang bersangkutan.

Prinsip 9

Penahanan harus dilakukan di tempat umum yang secara khusus dimaksudkan untuk tujuan ini; ketika, untuk alasan praktis, ini tidak terjadi, pencari suaka atau imigran harus ditempatkan di tempat yang terpisah dari tempat orang-orang yang dipenjara berdasarkan hukum pidana.

Prinsip 10

Kantor Komisaris Tinggi untuk Pengungsi (UNHCR), Komite Internasional Palang Merah (ICRC) dan, jika sesuai, organisasi non-pemerintah yang berwenang harus diberi akses ke tempat-tempat penahanan.

Namun pada kenyataannya sering terjadi pelanggaran pada prinsip ke 7 yaitu batas waktu pendetensiannya. Berdasarkan pasal 85 ayat 2 Undang-Undang Keimigrasian yang mengemukakan Dalam hal Deportasi sebagaimana dimaksud pada ayat (1) belum dapat dilaksanakan, detensi dapat dilakukan dalam jangka waktu paling lama 10 (sepuluh) tahun. Pendetensian yang mencapai 10 tahun tentu 
menambah berat beban keuangan yang dikeluarkan oleh negara, apalagi jika telah lebih dari 10 tahun.

Solusi lain dapat dilihat pada pasal 85 ayat 3 UndangUndang Keimigrasian yang mengemukakan Menteri atau Pejabat Imigrasi yang ditunjuk dapat mengeluarkan Deteni dari Rumah Detensi Imigrasi apabila jangka waktu sebagaimana dimaksud pada ayat (2) terlampaui dan memberikan izin kepada Deteni untuk berada di luar Rumah Detensi Imigrasi dengan menetapkan kewajiban melapor secara periodik. Namun solusi ini tidak begitu berguna jika tidak ada yang ingin menjadi penjamin deteni tersebut.

Penyelesaian terbaik adalah dengan aksesi Convention Relating To The Status Of Stateless Persons dan melakukan reservasi terhadap pasal-pasal yang menyesuaikan dengan selective policy keimigrasian Indonesia. Reservasi ialah menandatangani, meratifikasi, menerima, menyetujui, atau ikut serta dalam suatu ketentuan tertentu dari perjanjian international bagi dirinya. Aksesi yakni ikut serta suatu negara, yang bukan negara penandatangan suatu perjanjian internasional, dalam perjanjian internasional tersebut dengan status yang sama dengan negara pihak penandatangan yang pertama. ${ }^{15}$

Dengan melakukan hal tersebut setidaknya mampu membuat Indonesia mendapatkan kepastian hukum terhadap penanganan orang tanpa kewarganegaraan (Stateless person) bukan pengungsi di Indonesia dan tidak diberatkan dengan banyaknya kewajiban yang harus dipatuhi karena telah melakukan reservasi pada hampir seluruh konvensi tersebut. Kecuali untuk Pasal 1 (rumusan orang tanpa kewarganegaraan dan klausa-klausa pengecualian), Pasal 3 (nondiskriminasi),

15 Sugeng Istanto. Hukum Internasional EdisiRevisi, Cahaya Atma Pustaka, Yogyakarta, Cet. 5, 2018, hal. 100-101 
Pasal 4 (kebebasan beragama), Pasal 16 (1) (akses terhadap peradilan), dan Pasal 33 sampai 42 (klausa-klausa akhir) ${ }^{16}$.

Sehingga kasus seperti Zlavic yang telah diketahui sebagai deteni Stateless yang bukan pengungsi dikarenakan tidak ada negara yang mengakuinya dan ia juga tidak dapat menunjukkan bukti bahwa ia adalah seorang warga negara. Dalam penyelesaiannya, berdasarkan Convention Relating To The Status Of Stateless Persons dapat dengan pemberian bukti identitas berdasarkan Article 27 atau pembuatan dokumen perjalanan khusus orang tanpa kewarganegaraan (Stateless person) berdasarkan Article 28, dan tentunya dapat dikenai biaya pajak berdasarkan Article 29 sebagai pemasukan Negara. Sehingga dapat dicegah masa pendetensiannya yang tidak lebih dari 10 tahun.

Sedangkan pada kasus Sajjad Yaqub dan keluargnya yang merupakan Final Rejected Person atau deteni yang menjadi Stateless setelah hilangnya status pencari suakanya dapat diberikan Tindakan Administrasi Keimigrasian yang berdasarkan pasal 75 ayat 2 Undang-Undang Keimigrasian mengemukakan Tindakan Administratif Keimigrasian sebagaimana dimaksud pada ayat (1) dapat berupa:

a. pencantuman dalam daftar Pencegahan atau Penangkalan;

b. pembatasan, perubahan, atau pembatalan Izin Tinggal;

c. larangan untuk berada di satu atau beberapa tempat tertentu di Wilayah Indonesia;

d. keharusan untuk bertempat tinggal di suatu tempat tertentu di Wilayah Indonesia;

e. pengenaan biaya beban; dan/atau

f. Deportasi dari Wilayah Indonesia.

Jika ia beserta keluarganya dideportasi, maka berdasarkan Article 31 Convention Relating To The Status of Stateless Person dapat diberikan jangka waktu untuk

16 UNHCR, Op. Cit, hal. 13

Uti Possidetis: Journal of International Law, Vol. 1, No. 3 (2020) 
mendapatkan izin masuk ke negara lain, dengan didampingi pemerintah Indonesia sebagai negara peserta dan UNHCR atau IOM sebagai badan yang menyalurkan mereka ke negara tersebut.

\section{Penutup}

Berdasarkan pembahasan di atas, artikel ini menyimpulkan 2 hal penting terhadap orang tanpa kewarganegaraan (Stateless persons) diatur secara spesifik pada Convention Relating To The Status of Stateless Persons. Konvensi ini memberikan penjelasan umum, status hukum, mendapatkan pekerjaan yang layak, kesejahteraan, tindakan administratif, dan klausa final dari konvensi tersebut yang mampu menegaskan bahwa ini adalah konvensi yang melindungi orang tanpa kewarganegaraan (Stateless persons) secara lengkap terhadap negara yang sedang menghadapi kasus orang tanpa kewarganegaraan (Stateless persons).

Pengaturan orang tanpa kewarganegaraan (Stateless persons) di Indonesia masih belum diatur secara tegas dan dalam penanganan nya terhadap orang tanpa kewarganegaraan (Stateless persons) cenderung lamban, yang mengakibatkan pendetensian melebihi ambang batas. Hal ini tentu membuat beban negara bertambah sebagai akibat dari pendetensian yang lama dan terbatasnya hak-hak mereka selama didetensi.

\section{Referensi}

\section{Buku}

Gatot Supramono. Hukum Orang Asing di Indonesia. Sinar Grafika. Jakarta. 2012.

Marilyn Achiron. Nationality and Statelessness: A Handbook for Parliamentarians. Centrales de Lausanne. Switzerland. 2005. 
Sugeng Istanto. Hukum Internasional Edisi Revisi. Cahaya Atma Pustaka. Yogyakarta. Cet. 5. 2018.

UNHCR. Melindungi Hak-Hak Orang-Orang Tanpa Kewarganegaraan. 2010.

\section{Jurnal/KaryaIlmiah}

A. Amrullah Armansyah, dkk,. Penegakan Hukum Keimigrasian Terhadap Warga Negara Asing Anak Buah Kapal (ABK) Tangkap Ikan Secara Ilegal. Pleno Jure. Vol. 9. 2019.

Agung Sulistyo Purnomo. Pandangan Hak Asasi Manusia terhadap Pembiaran Orang dengan Status 'Stateless' di Indonesia (Studi Kasus: Danko Nizar Zlavic). Jurnal Ilmiah Kajian Keimigrasian. Vol. 2. No. 1. 2019.

Asih Saraswati. Convention Relating to the Status of Stateless Persons. Jurnal Hukum Internasional. Vol.2 No. 1. 2004.

Kusniati, R. (2011). Sejarah Perlindungan Hak Hak Asasi Manusia dalam Kaitannya dengan Konsepsi Negara Hukum.https://onlinejournal.unja.ac.id/jimih/article/vi ew/537

M. Alvi Syahrin. Penerapan Hukum Deteni Tanpa Kewarganegaraan (Stateless) yang Ditahan Lebih Dari 10 (Sepuluh) Tahun di Rumah Detensi Imigrasi Jakarta: Studi Kasus Danko Nizar Zlavic. Jurnal Fiat Justicia, Vol. 3, No. 2. 2017.

Widodo Ekatjahjana. Masalah Kewarganegaraan dan tidak berkewarganegaraan,. Jurnal Ilmu Hukum Inovatif, Vol. 2., No. 3. 2010.

\section{Laman}

https://www.unhcr.org/id/orang-orang-tanpa-

kewarganegaraan

https://kumparan.com/manadobacirita-admin/duka-pencari-

suaka-20-tahun-tanpa-kewarganegaraan-disetopnya-

bantuan-1550307880236333677

Uti Possidetis: Journal of International Law, Vol. 1, No. 3 (2020) 
Khald Fadjri Siddiq \& Budi Ardianto

https://utamanews.com/sosial-budaya/Dilema-10-WN-

Afghanistan-di-Manado--Bagaimana-Statusnya-Saat-ini-

Peraturan Perundang-Undangan

Undang-Undang Nomor 6 Tahun 2011 tentang Keimigrasiaan Peraturan Pemerintah Republik Indonesia Nomor 2 Tahun 2007 tentang Tata Cara Memperoleh, Kehilangan, Pembatalan, dan Memperoleh Kembali

Kewarganegaraan Republik Indonesia.

Convention Relating to The Status of Stateless Persons 1954 